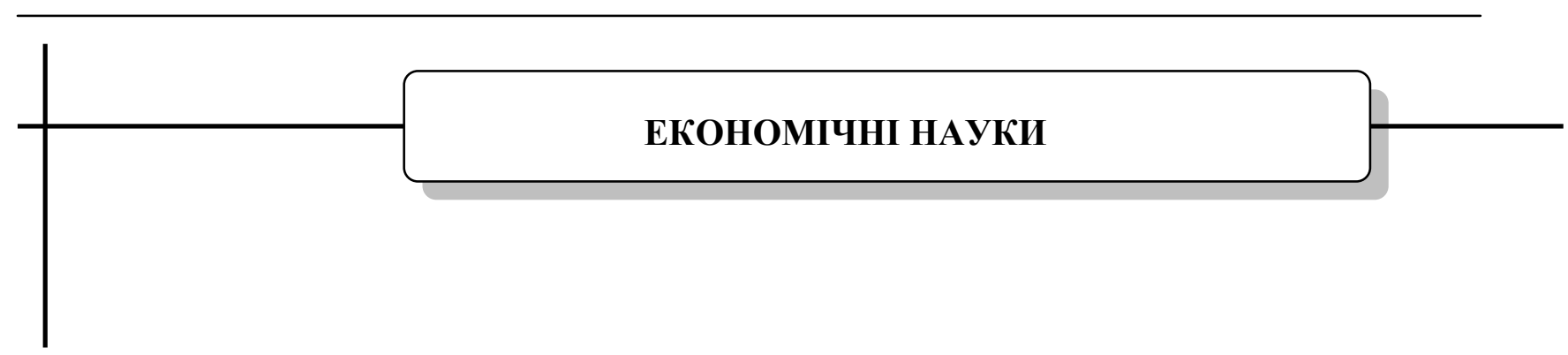

УДК 338.43:631.1.016

DOI: $10.15587 / 2313-8416.2016 .60349$

\title{
ALGORITHM OF DEVELOPING COMPETITIVE STRATEGIES AND THE TRENDS OF REALIZING THEM FOR AGRICULTURAL ENTERPRISES
}

\author{
(C) V. Boiko
}

The paper specifies basic stages of developing and realizing the strategy of enhancing competitiveness of enterprises and represents an appropriate algorithm. The study analyzes the economic indexes and results of the activity of the agrarian enterprises in Kherson region and provides competitive strategies of efficient development of agrarian enterprises with different levels of competitiveness and specifies the ways of realizing them which will contribute to the optimal use of the available strategic potential

Keywords: competitiveness, competitive strategies, sources of competitive advantages, agricultural enterprises, stages of developing and realizing a strategy

У статті визначено основні етапи формування і реалізації стратегії підвищення конкурентоспроможності підприємств та запропоновано відповідний алгоритм. Проаналізовано економічні показники та результати діяльності аграрних підприємств Херсонської області, на основі чого сформовано конкурентні стратегї ефективного розвитку аграрних підприємств з різним рівнем конкурентоспроможності та вказано напрями їх реалізації, які сприятимуть оптимальному використанню наявного стратегічного потенціалу

Ключові слова: конкурентоспроможність, конкурентні стратегї, джерела конкурентних переваг, аграрні підприємства, етапи розробки та реалізачї стратегії

\section{Introduction}

The main task of agricultural enterprises in market economic conditions is to enhance competitiveness and efficient activity, which is a precondition of their strategic development. It becomes possible in the following conditions: rapid adaptation of agricultural producers to the environmental changes; timely identification and support of their own competitive advantages; realization of the innovative model of development; optimization of investment support and rational distribution among the activities.

\section{Analysis of the previous research findings} and publications

The problem of competitiveness of agricultural enterprises has been essential for such scientists as S. Kvasha [1], M. Malik [2], O. Nuzhna [3], O. Shkolnyj [4] and others. I. Hutorova [5], V. Zbarskyi [6], M. Misevych [7], L. Yevchuk [8] have studied the problems of evaluation of agricultural enterprises based on the identification of different factors of their impact on competitiveness.

\section{Task statement}

In the Ukrainian scientific editions the theoretical and methodical approaches to choosing an optimal variant of strategies for agricultural enterprises with a low level of competitiveness, i. e. for the enterprisesoutsiders, have been substantiated insufficiently. The purpose of the article is substantiation of the theoretical and methodical principles of developing and enhancing competitiveness of agricultural enterprises, working out alternatives and competitive strategies of their development based on the diagnostics of the business environment.

4. Generating competitive strategies of the development of agrarian enterprises with identifying management decisions

In order to increase competitiveness of agricultural enterprises in the region it is expedient to develop their competitive strategies, i. e. to define the priority trends of the enterprise development based on the identification and efficient use of competitive advantages. The paper represents the competitive strategies developed for different groups on the basis of using analytical information and conducting marketing research and evaluating the competitiveness of the resource potential and products of the agricultural enterprises in the region. Therefore, the choice of a competitive strategy of the enterprise depends on the purposes of its activity and the chosen way of achieving the competitive advantages.

The paper claims that the process of developing and achieving competitive strategies of agricultural 
enterprises must imply the stages from diagnosing the business environment to developing a certain strategy of increasing the competitiveness of agricultural enterprises.

Considering the above mentioned information we have offered the algorithm of developing the strategy of increasing the competitiveness of an agricultural enterprise, which is given in Fig. 1.

Taking into account the State strategy of developing the agrarian sector of Ukraine's economy (for the period till 2020) [9], the mission of the investigated agricultural enterprises is to provide the consumers of the region with different incomes with qualitative, safe, variable agricultural products meeting European standards and for reasonable prices. This will make it possible to develop competitive advantages, increase the level of efficiency and competitiveness of agricultural enterprises and create an economic base for sustainable development of the agrarian sector and rural areas of the region.
In order to achieve this mission it is necessary to bring its content to each level of a management system and an executor at the enterprise, define everybody's contribution into the strategic success of the enterprise on the whole. It can be provided by decomposing aims and tasks, i. e. building "the tree of aims", where certain quantitatively determined tasks are set, which form the basis of certain types of work.

The strategic aims of the activity of agricultural enterprises in Kherson region are:

- to provide food safety of the region;

- to increase competitiveness of products, productivity of the branches, efficiency of production;

- to work out activities concerning the environment protection, restoration, conservation and increasing soil fertility; the region;

- to increase the income of farmworkers in

- to promote the social development of rural areas;

- to use and preserve land resources rationally.

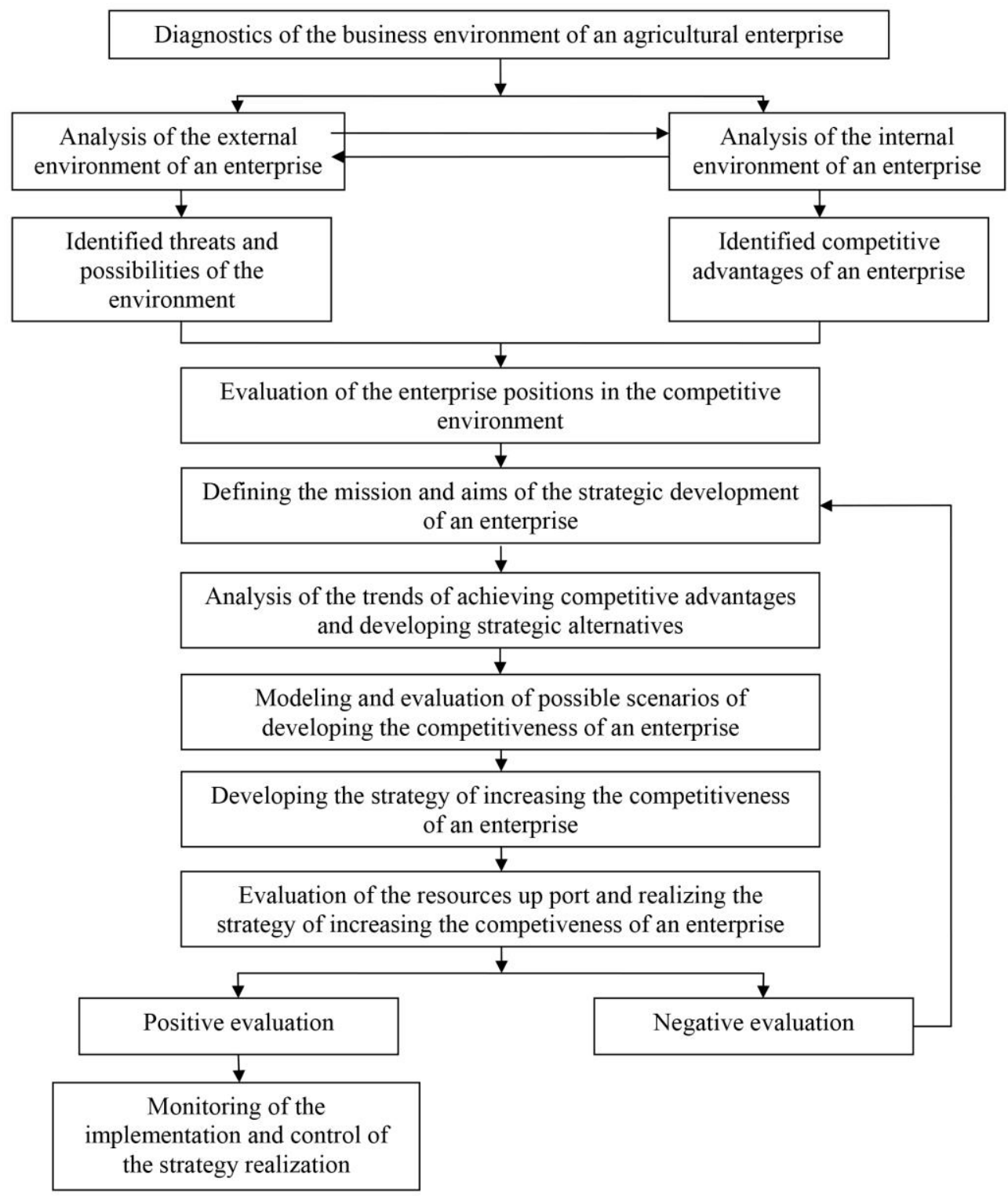

Fig. 1. Algorithm of developing and realizing the strategy of increasing the competitiveness of an enterprise. The source: made by the author 
The major trend of realizing the competitive strategy of an agricultural enterprise till 2020 must lie in increasing the competitiveness of agricultural production. It is possible only in the following ways:

1. Reducing the cost price of agricultural products depending on the structure of production and type of products by $3-9 \%$ at the expense of increasing the volume of production and intensifying crop production and enhancing productivity and expanding livestock production. It will be facilitated by the following factors:

- increasing the volume of gross agricultural production 1.4 times;

- increasing the volume of crop production 1.3 times (including grain production -1.4 times), livestock production - 1.7 times (including milk production -1.8 times, beef production -1.8 times, pork production -2.2 times);

- increasing manufacturability and reducing material capacity of agricultural products;

- increasing the share of lands, cultivated by the technologies of zero or minimized tillage to two thirds;

- increasing the share of agricultural enterprises engaged in the area of innovations to $25 \%$;

- increasing market adaptability of agricultural producers;

- increasing the share of agricultural products sold within long-term and guaranteed contracts, the whole sale volume to $50 \%$.

2. Covering over $80 \%$ of farms and small farm units with agricultural cooperatives.

3. Covering over $90 \%$ of the branch entities with the insurance of agricultural risks.

4. Increasing the amount of the credit resources involved by agricultural producers at least 3.5 times.

5. Increasing economic effectiveness of agricultural production:

- increasing the volume of export of agricultural products and food products 2.8 times till 2020;

- increasing tax funds to the consolidated budget coming from agricultural enterprises 2.4 times;

- increasing gross value-added costs, generated by agriculture in 2020, 2.8 times comparing with that of generated in 2014. production:

6. Increasing the social input of agricultural

- increasing gross expenses for remuneration of labor 2.6-2.8 times;

- increasing average monthly wages of agricultural workers to the average in the branches of economy and increasing work productivity 2 times;

- reducing the number of unemployed and increasing the level of employment in rural areas to the average level in the economy.

According to the State strategy of regional development [9] agricultural enterprises of Kherson region have tactical aims, the achievement of them will enhance competitiveness of the agrarian sector of the region. In order to increase profitability of an agricultural enterprise it is necessary:

- to increase the area for profitable crops (grains, legumes, soybeans) at the expense of reducing the area for unprofitable crops;
- to minimize unprofitable crops at the expense of reducing the area for vegetables and melons;

- to provide the market with high-quality agricultural products;

- to provide agricultural enterprises with original, elite and reproductive seeds, pedigree cattle and poultry;

- to reduce commercial cost price;

- to reduce fixed costs per unit of production;

- to extend the range of products at the expense of growing crops and raising animals with high export potential (rape, sheep for wool).

In order to improve calculations and reduce debts of an enterprise it is expedient:

- to develop the system of controlling timely repayment of debit debts;

- to develop the system of controlling timely repayment of debit debts.

Expending the market share and exploring new markets requires:

- increasing the volume of production;

- expanding trading network;

- increasing expenses for advertising and promoting products to customers;

- improving schemes of distributing products,

The stabilization of financial condition requires:

- to increase liquidity of assets (to $0.2-0.3$ );

- to reduce the amount of credit debts;

- to increase financial flexibility;

- to increase investments.

In order to increase the efficiency of using basic production assets it is necessary:

- to eliminate old depreciated machines, equipment and tools or technically outdated ones; or leasing.

- to update production facilities by purchasing

Maintaining leading positions at the market requires:

- to increase competitiveness at the expense of intensifying production;

- to involve additional investments and appropriate government support;

- to increase the amount of producing profitable products (grains and legumes, soybeans, rape and milk);

- to ensure timely fulfillment of contract commitments.

In order to meet the requirements of quality standards it is necessary:

- to implement the system of agrotechnical measures;

- to implement innovative products, advances of science and technology;

- to develop the system of soil, water and air protection.

In order to enhance productivity of labor and efficiency of using labor resources at agricultural enterprises it is expedient:

- to ensure the optimal number and structure of personnel;

- to increase the level of employees' qualification at the expense of retraining the workers;

- to continue activities aimed at normalizing the work; 
- to take measures to improve working conditions and health care; of labor.

- to provide an appropriate level of remuneration

Therefore while developing the strategy of increasing the competitiveness of agricultural enterprises it is necessary to consider the average annual number of workers, the amount of production costs, commercial cost price of products, the level of profitability, the achieved level of the integral index of competitiveness; the market environment of agricultural enterprises; the mission and structured aims of activity (Fig. 2).

Thus, enterprises with the level of the integral index of competitive potential ranging from 12 to 15 scores (belonging to the group of highly profitable and profitable enterprises, taking a strong position in the competition), must choose the competitive strategy of leading based on innovative values, its major aim is to maintain the leading position.

The result of realizing this strategy must lie in achieving competitive advantages of high order: implementing innovative technologies of growing crops and raising animals; unique and ecological products; perma- nent monitoring of the market changes and branched network of retailers; improving social security and income of workers.

The optimal choice for enterprises with a medium level of the integral index of competitive potential (from 9 to 11 scores) is a competitive strategy of developing competitiveness, which implies searching for new markets; increasing the marker share of an enterprise; maximizing profits, minimizing losses.

Enterprises with a low level of the integral index of competitiveness (5-9 scores) are outsiders at the market and are considered low profitable or unprofitable enterprises, they must implement the competitive strategy of the survival based on cooperation, which is cost efficient and has organizational character.

Competitive advantages from realizing it are the advantages of low order and can be easily achieved or imitated by the competitors. If the management of such an enterprise is not able to solve these problems, it is expedient to use the strategy of leaving the market, winding up the business or reorganizing it. The latter will intensify the process of expanding agricultural enterprises and become the tool of increasing their efficiency.

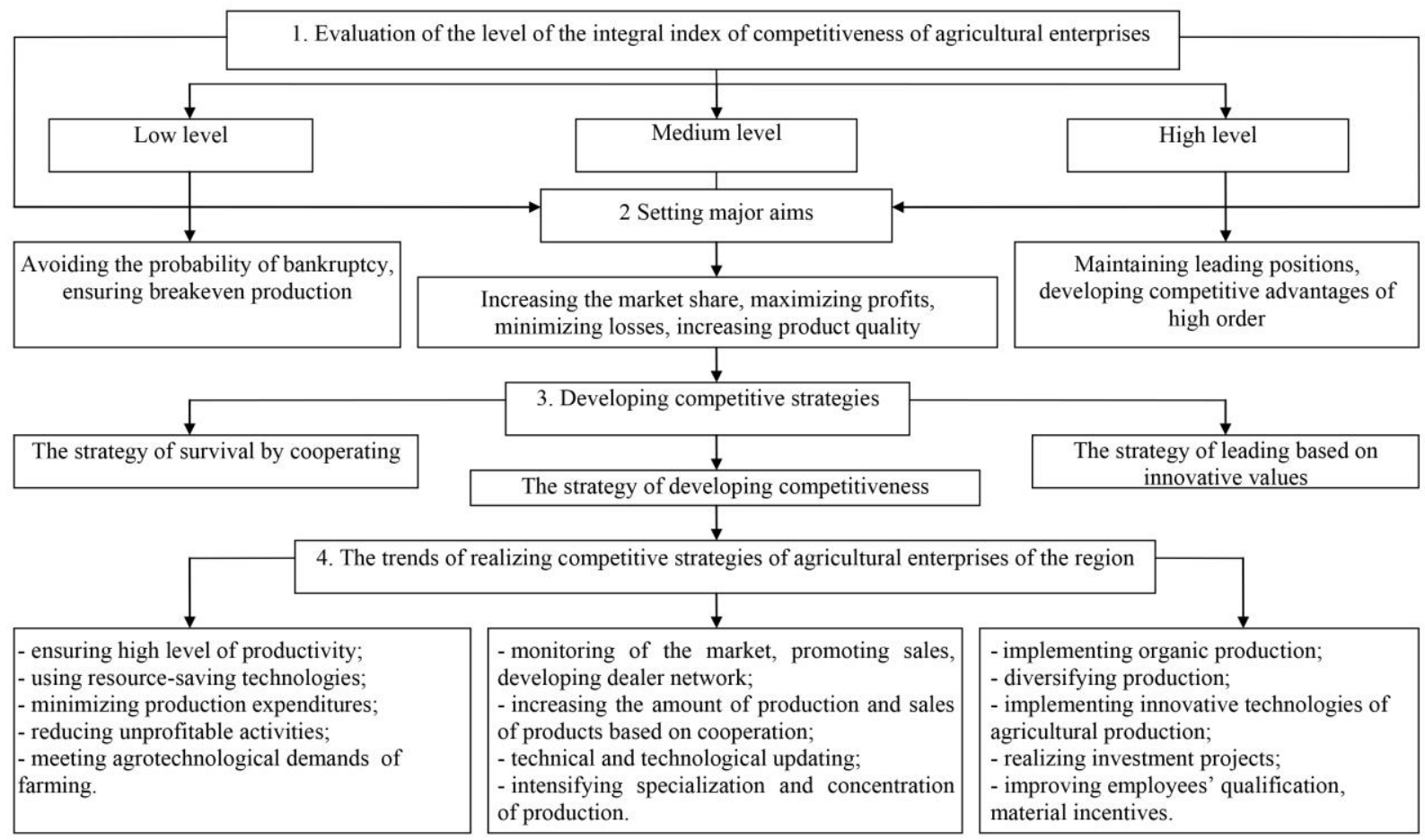

Fig. 2. The algorithm of defining the trends of realizing competitive strategies of agricultural enterprises.

The source: improved by the author

\section{Results of the research}

On the basis of diagnosing the business environment of agrarian enterprises it is necessary to improve the algorithm of developing and implementing the strategy of enhancing competitiveness, since in the economic literature there is no single methodological approach to investigating it, especially in the agrarian sphere. We suggest identifying the position of an enterprise among its competitors at the stage of analyzing the business environment; modeling and estimating the probable scenar- ios of the development of enterprises - after generating strategic alternatives.

The results of the conducted strategic analysis allow for affirming that the main reasons of the low level of competitiveness of the studied agrarian enterprises are insufficient level of using marketing instruments, inefficiency of management, low level of competitiveness of the agricultural products. In order to improve competitiveness of the agrarian enterprises in the region on the basis of their competitive advantages we have 
proposed proper competitive strategies. The development of competitive strategies for different groups of enterprises must be realized on the basis of analytical information, results of marketing research and estimation of competitiveness of resource potential and products of the enterprises in the region. Thus, the development of a competitive strategy depends on the aims of the activity and the chosen method of achieving competitive advantages.

\section{Conclusions}

In generating the strategy of enhancing competitiveness of agrarian enterprises we take into account the level of the integral index of agrarian enterprises; the mission and structured aims of the activity. The work represents competitive strategies of the effective development of enterprises with different levels of competitiveness on the basis of the integral index of competitiveness, namely: the strategy of leading based on creating innovational value; the strategy of developing competitiveness; the strategy of survival through cooperation.

The enterprises with a strong competitive position will increase the level of their competitiveness after implementing this strategy and will take a leading position in their area. The enterprises with a medium position will have a strong competitive position. The implementation of this strategy by the enterprises-outsiders will allow them to enhance their competitive position and survive in the market.

\section{References}

1. Kvasha, S. M. Konkurentospromozhnist' vitchyznjanoi' sil's'kogospodars'koi' produkcii' na svitovomu agrarnomu rynku [Text] / S. M. Kvasha // Ekonomika APK. - 2006. - Issue 5. - P. 99-104.

2. Malik, M. J. Konkurentospromozhnist' agrarnyh pidpryjemstv: metodologija i mehanizmy [Text]: monografija / M. J. Malik, O. A. Nuzhna. - Kyiv: NNC IAE, 2007. - 270 p.

3. Nuzhna, O. A. Ocinka rivnja konkurentospromozhnosti sil's'kogospodars'kyh pidpryjemstv [Text] / O. A. Nuzhna // Ekonomika APK. - 2006. - Issue 4. - P. 110-115.

4. Shkol'nyj, O. O. Organizacijno-ekonomichni mehanizmy upravlinnja konkurentospromozhnistju agrarnyh pidpryjemstv [Text]: monografija / O. O. Shkol'nyj. - Uman: Vydavnyctvo UDAU, 2007. - 308 p.

5. Gutorova, I. V. Teoretyko-metodychni zasady analizu ta ocinky konkurentospromozhnosti sil's'kogospodars'kyh pidpryjemstv [Text] / I. V. Gutorova // Visnyk HNTUSG, serija «Ekonomichni nauky». - 2011. - Issue 112. - P. 204-212.
6. Zbars'kyj, V. K. Konkurentospromozhnist' vysokotovarnyh sil's'kogospodars'kyh pidpryjemstv [Text] / V. K. Zbars'kyj, M. A. Misevych; V. K. Zbars'kii (Ed.). - Kyiv: NNC IAE, 2009. - $310 \mathrm{p}$.

7. Misevych, M. A. Potencijna konkurento-spromozhnist' vysokotovarnyh sil's'kogospodars'kyh pidp-ryjemstv Zhytomyrs'koi' oblasti [Text] / M. A. Misevych // Ekonomika APK. - 2007. - Issue 3. - P. 126-132.

8. Jevchuk, L. A. Strategichne upravlinnja konkurentospromozhnistju sil's'kogospodars'kyh pidpryjemstv [Text]: monografija / L. A. Jevchuk. - Mykolaiv: Vyd-c': Prokopchuk T. Ju., 2010. -340 p.

9. Strategija rozvytku agarnogo sektoru ekonomiky Ukrai'ny na period do 2020 roku [Text]. - Ministerstvo agrarnoi' polityky ta prodovol'stva Ukrai'ny. - Kyiv, 2013. - Available at: http://minagro.gov.ua/node/7644

10. Fedonin, O. S. Potencial pidpryjemstva: formuvannja ta ocinka [Text]: navch. pos. / O. S. Fedonin, I. M. Rjepina, O. I. Oleksyk. - Kyiv: KNEU, 2004. - 316 p.

\section{References}

1. Kvasha, S. M. (2006). Konkurentospromozhnist vitchyznianoii silskohospodarskoii produkcii na svitovomu agrarnomu rynku. Ekonomika APK, 5, 99-104.

2. Malik, M. Y., Nuzhna, O. A. (2007). Konkurentospromozhnist agrarnykh pidpryiemstv: metodologiia i mekhanizmy. Kyiv: NNC IAE, 270.

3. Nuzhna, O. A. (2006). Otsinka rivnia konkurentospromozhnosti silskohospodarskykh pidpryiemstv. Ekonomika APK, 4, 110-115.

4. Shkolnyj, O. O. (2007). Organizaciino-ekonomichni mekhanizmy upravlinnia konkurentospromozhnistyu agrarnykh pidpryiemstv. Uman: Vydavnytstvo UDAU, 308.

5. Hutorova, I. V. (2011). Teoretyko-metodychni zasady analizu ta otsinky konkurentospromozhnosti silskohospodarskykh pidpryiemstv. Visnyk XNTUSG, seriia «Ekonomichni nauky», 112, 204-212.

6. Zbarskyi, V. K., Misevych, M. A.; Zbars'kiy V. K. (Ed.) (2009). Konkurentospromozhnist vysokotovarnykh silskohospodarskykh pidpryiemstv. Kyiv: NNC IAE, 310.

7. Misevych, M. A. (2007). Potenciina konkurentospromozhnist vysokotovarnykh silskohospodarskykh pidpryiemstv Zhytomyrskoii oblasti. Ekonomika APK, 3, 126-132.

8. Yevchuk, L. A. (2010). Strategichne upravlinnia konkurentospromozhnistiu silskohospodarskykh pidpryemstv. Mykolayiv: Vyd-cz: Prokopchuk T. Yu., 340.

9. Derzhavna strategiia rozvytku agarnoho sektoru ekonomiky Ukraiiny na period do 2020 roku (2013). Ministerstvo agrarnoii polityky ta prodovolstva Ukraiiny. Kyiv. Available at: http://minagro.gov.ua/node/7644

10. Fedonin, O. S., Riepina, I. M., Oleksyk, O. I. (2004). Potentsial pidpryiemstva: formuvannia ta otsinka. Kyiv: KNEU, 316.

Boiko Viktoriia, Candidate of Economic sciences, Associate Professor, Department of Enterprise Economics, State higher education institution "Kherson State Agricultural University", Rosa Luxemburg str., 23, Kherson, Ukraine, 73006

E-mail: boyko_va@mail.ua 